\title{
NIAT MELAKUKAN WHISTLEBLOWING: PERSEPSI MAHASISWA DIPLOMA III EKONOMI
}

\begin{abstract}
This study aims to examine the factors that can affect the economics student intention of doing whistleblowing. The variables used in this study refer to the Theory of Planned Behavior is the attitude towards behavior, subjective norms, and perceived behavioral control which will then be tested for its effect on the intention to do whistleblowing. This study will examine these factors partially and simultaneously.

This study uses a population of all active diploma 3 economics students in one of the private universities in Yogyakarta. While the number of samples used in this study using the Slovin Formula as many as 88 respondents. Data collection techniques in this study using a questionnaire with data analysis methods and tools using multiple regression analysis using SPSS version 16.

The results of this study indicate that the variable attitudes toward behavior and subjective norm partially positive influence on the intention of doing whistleblowing. While perceived behavior control variables do not have a positive effect on the intention to do whistleblowing. Simultaneously variable attitudes toward the behavior, subjective norms, and perceived behavioral control significantly influence the intention of doing whistleblowing.
\end{abstract}

Keywords: Attitude, Subjective Norm, Perceived Behavioral Control, Theory of Planned Behavior, Intention

\section{PENDAHULUAN}

Kecurangan selalu diidentikkan dengan tindakan buruk yang dapat memgakibatkan salah satu pihak mengalami kerugian. Hampir sebagian negara pernah mengalami kasus-kasus yang berkaitan dengan tindakan kecurangan. Tindakan kecurangan bisa terjadi dimana saja baik di lingkungan pemerintahan maupun swasta. Pelakunya pun bisa orang biasa yang tidak mempunyai kedudukan hingga orang yang menduduki posisi penting di tempat dimana mereka berada. Selain itu tindakan kecurangan bisa dilakukan seorang diri maupun dilakukan secara bersama-sama dengan perencanaan yang baik pula. Bentuk kecurangan dilakukan secara bersamaan atau terorganisir tentunya melibatkan banyak pihak, tidak hanya pihak atau orang yang berada didalam entitas saja tetapi pihak atau orang yang berada diluar entitas pun bisa bersama-sama melakukan tindakan kecurangan. Tindakan kecurangan akan terbongkar jika ada pihak atau orang yang berani membuka dan menentang tindakan-tindakan yang dapat merugikan orang banyak. Pihak atau orang yang berani membongkar atau mengungkap tindakan kecurangan tersebut dikenal sebagai seorang whistleblower (seorang pengadu) yang istilah tersebut mulai dikenal di Indonesia.

Terdapat banyak cara untuk mencegah terjadinya tindakan kecurangan di instansi atau lingkungannya. Sebagai contoh yang cukup populer diterapkan baik oleh instansi pemerintah maupun swasta adalah penerapan whistleblowing system (sistem pengaduan). Sistem tersebut memfasilitasi seorang pengadu untuk mengadukan atau melaporkan jika terjadi indikasi-indikasi tindakan kecurangan yang dapat merugikan tempatnya tanpa orang lain mengetahui bahwa ada yang melaporkan tindakan kecurangan dikarenakan sistem ini didesain kerahasiaannya. Tetapi sistem ini tidak bisa berjalan secara efektif tanpa adanya komitmen 
dari seluruh anggota organisasi untuk berpartisipasi menggunakan sistem ini (Winardi, 2013). Selain itu komitmen dari pimpinan atau atasan untuk menerapkan sistem ini secara penuh dan tidak memilih-memilih juga menjadi kunci sistem ini bisa berjalan secara efektif. Perlindungan yang bisa diberikan oleh pimpinan atau atasan terhadap seorang pengadu bisa juga menjadi faktor keberhasilan sistem ini berjalan efektif dikarenakan komitmen untuk melindungi seorang pengadu tersebut dibutuhkan agar seorang pengadu terbebas dari risiko pembalasan yang dilakukan oleh organisasi baik dari atasannya maupun dari rekan kerjanya (MesmerMagnus dan Viswesvaran, 2005).

Hampir disebagian tempat baik disektor pemerintahan maupun swasta tindakan kecurangan menjadi satu ancaman yang bisa merugikan banyak pihak. Hal ini juga tidak terlepas pada institusi pendidikan yang mengajarkan praktek-praktek yang sehat dan menjunjung tinggi nilai-nilai kejujuran. Pada institusi pendidikan dalam hal ini Universitas atau Perguruan Tinggi terdapat dua elemen didalamnya, yakni mahasiswa sebagai pihak yang menerima atau menikmati jasa dan juga dosen atau karyawan sebagai pengelola dan pemberi jasa di institusi pendidikan. Pihak pengelola dan pemberi jasa harus melaksanakan tugasnya dengan memegang teguh prinsip-prinsip kejujuran sehingga praktek-praktek yang dianggap tidak baik bisa diminimalisir. Selain itu mahasiswa sebagai penerima jasa juga harus bisa menjadi pengawas agar pengelola dan pemberi jasa bisa menjalankan tugasnya dengan benar.

Beberapa tahun belakangan ini institusi Perguruan Tinggi menjadi sorotan dikarenakan adanya kecenderungan telah terjadi tindakan kecurangan dalam hal ini adalah tindakan korupsi. Indonesia Corruption Watch merilis dua belas pola korupsi yang sering terjadi di lingkungan Perguruan Tinggi (www.antikorupsi. org). Beberapa pola diantaranya adalah kecurangan yang terjadi pada saat pemilihan rektor. Pada praktek ini umumnya kecurangan yang dilakukan adalah dalam bentuk suap untuk memenangkan salah satu calon tertentu. Selain itu pengadaan barang dan jasa menjadi pola atau modus yang paling banyak digunakan. Mekanisme pengadaan barang dan jasa yang kurang transparan menjadi faktor munculnya tindakan kecurangan. Sepanjang tahun 2016 tercatat 14 dari 37 kasus korupsi yang terjadi di Perguruan Tinggi adalah korupsi yang terjadi pada pengadaan barang dan jasa. Hal ini dibuktikan dengan ditetapkannya salah satu Rektor di Perguruan Tinggi sebagai tersangka oleh KPK atas korupsi pengadaan barang dan jasa. Selain dua pola atau modus diatas masih banyak lagi pola atau modus yang sering terjadi di Perguruan Tinggi antara lain masalah anggaran internal, penjualan aset Perguruan Tinggi yang hasilnya tidak masuk ke kampus, korupsi dalam pembagian beasiswa, juga praktik pungutan liar, gratifikasi, dana hibah dan CSR, serta suap dan tidak menutup kemungkinan terdapat pola atau modus lain yang bisa memicu terjadinya tindakan kecurangan atau korupsi. Melihat banyaknya pola atau modus kecurangan maka dibutuhkan peran aktif dari seluruh elemen yang berada di Perguruan Tinggi dalam hal ini adalah mahasiswa. Peran sebagai seorang pengawas terhadap jalannya aktifitas di Perguruan Tinggi bisa menjadi memunculkan niat mahasiswa untuk mengadukan atau menjadi seorang pengadu jika terjadi tindakan kecurangan atau korupsi di institusinya.

Seorang pengadu harus mempunyai niatan terlebih dahulu sebelum melakukan pengungkapan tindakan kecurangan dikarenakan niat tersebut yang akan mempengaruhi seseorang untuk melakukan perbuatan tertentu atau tidak. Terdapat faktor yang dapat memprediksi niat seseorang untuk melakukan perbuatan 
atau tidak melakukan perbuatan tersebut. Faktor tersebut berasal dari teori yang diungkapkan oleh Ajzen (1991) yaitu sikap terhadap perilaku, norma subjektif, dan kontrol perilaku persepsian. Sebelum berniat untuk melakukan suatu perbuatan atau tidak, seseorang harus mempunyai sikap terlebih dahulu terhadap perbuatan tersebut. Sikap inilah yang menjadi sebuah persepsi bahwa perilaku yang akan dilakukan berdampak positif atau negatif. Selain persepsi mengenai sikap positif atau negatif tehadap suatu perilaku, faktor orang-orang disekitarnya juga mempunyai peranan penting untuk melakukan atau tidak melakukan perilaku tersebut. Kemudian faktor kemudahan untuk melakukan perbuatan tersebut juga menjadi pertimbangan seseorang melakukan atau tidak melakukan. Berdasarkan penjelasan tersebut maka dapat dirumuskan beberapa pertanyaan penelitian, antara lain:

1. Apakah sikap berpengaruh positif terhadap niat melakukan pengaduan?

2. Apakah norma subjektif berpengaruh positif terhadap niat melakukan pengaduan?

3. Apakah kontrol perilaku berpengaruh positif terhadap niat melakukan pengaduan ?

\section{Tujuan Penelitian}

1. Berdasarkan pertanyaan penelitian diatas, maka tujuan peneltian ini antara lain:

2. Menguji pengaruh sikap terhadap niat melakukan pengaduan.

3. Menguji pengaruh norma subjektif terhadap niat melakukan pengaduan.

4. Menguji pengaruh kontrol perilaku terhadap niat melakukan pengaduan.

\section{TINJAUAN PUSTAKA dan PENGEMBANGAN HIPOTESIS}

\section{Pengaruh Sikap Terhadap Niat Melakukan Pengaduan}

Sikap merupakan pandangan atau penilaian seseorang tentang untung atau rugi jika suatu perilaku tersebut harus dilakukan (Ajzen, 1991). Sikap juga bisa didefinisikan sebagai suatu bentuk penilaian yang bersifat individual tentang seberapa besar mereka menyetujui atau tidak menyetujui perilaku tertentu (Park dan Blenkinsopp, 2009). Selain itu, Hartono (2008) menjelasakan bahwa sikap adalah suatu bentuk evaluasi diri yang berkaitan dengan suatu kepercayaan (belief) atau perasaan (affect) positif atau negatif dari individual jika perilaku tersebut harus dilakukan. Oleh karena itu bisa disimpulkan bahwa sikap merupakan penilaian positif atau negatif seseorang terhadap perilaku. Sikap terhadap perilaku ditentukan oleh keyakinan yang mereka miliki terhadap perilaku. Sikap terbentuk dari sebuah keyakinan tentang keuntungan atau kerugian dalam melakukan perilaku.

Sebelum melakukan sebuah perilaku tertentu pastilah setiap individu akan mempunyai pandangan sebagai bentuk sikap terhadap perilaku tersebut. Termasuk juga bagi mahasiswa yang ingin mengadukan sesuatu yang dirasakan akan merugikan pihak-pihak tertentu. Mahasiswa sebagai seorang calon pengadu akan berpikir terlebih dahulu sebelum melakukan pengaduan. Proses berpikir tersebut yang merupakan sikap dalam bentuk evaluasi diri terhadap sebuah perilaku tentang seberapa besar manfaat yang didapatkan jika perilaku tersebut dilakukan. Mahasiswa akan melakukan pengaduan (whistleblowing) jika terdapat sebuah perilaku atau perbuatan tertentu dianggap tidak benar dan dapat merugikan salah satu pihak atau beberapa pihak. Selain itu pandangan atau persepsi mahasiswa terhadap sebuah perilaku akan membentuk 
sikap yang positif atau negatif terhadap perilaku tersebut. Mahasiswa cenderung mempunyai niat untuk melakukan pengaduan atau menjadi pengadu jika mahasiswa berpandangan atau menilai bahwa perilaku yang akan dilakukannya tersebut dapat bermanfaat bagi banyak pihak atau perilaku yang akan dilakukannya dapat mencegah pihak-pihak tertentu atau beberapa pihak dari kerugian atau kerusakan yang lebih berat. Sebaliknya mahasiswa cenderung untuk enggan atau tidak memiliki niat untuk melakukan pengaduan atau menjadi pengadu jika mahasiswa berpandangan atau menilai bahwa perilakunya tersebut cenderung akan sia-sia atau tidak memiliki manfaat bagi pihak-pihak tertentu atau beberapa pihak. Berdasarkan penjelasan diatas maka dapat dirumuskan sebuah hipotesis sebagai berikut:

\section{H1: Sikap terhadap perilaku berpengaruh positif terhadap niat melakukan pengaduan. Pengaruh Norma Subjektif Terhadap Niat Melakukan Pengaduan}

Norma subjektif sering kali diartikan sebagai faktor lain yang berasal dari luar individu yang dapat mempengaruhiindividu tersebutuntukmelakukanatautidakmelakukan sesuatu. Ajzen(1991)mengungkapkan bahwa norma subjektif dapat diartikan sebagai suatu bentuk tekanan sosial yang dapat mempengaruhi seseorang untuk melakukan atau tidak melakukan suatu perilaku. Hartono (2008) menyebutkan bahwa norma subjektif merupakan persepsi atau pandangan seseorang terhadap kepercayaan-kepercayaan orang lain yang akan mempengaruhi niat seseorang untuk melakukan atau tidak melakukan perilaku. Selain itu Park dan Blenkinsopp (2009) menjelaskan bahwa norma subjektif dapat dipengaruhi oleh keyakinan normatif yang merupakan keyakinan seseorang bahwa perilaku yang akan dilakukannya akan mendapat persetujuan dari orang-orang di sekitarnya. Seseorang akan melakukan suatu perilaku jika perilaku yang dilakukannya merupakan perilaku yang positif dan mendapat dukungan dari orang-orang disekitarnya, seperti keluarga, teman, rekan kerja, dan atasan. Begitupula sebaliknya, perilaku tersebut cenderung untuk tidak dilakukan jika orang-orang disekitar individu tidak menyetujui (Putra dan Basuki, 2015).

Mahasiswa sebagai seorang calon pengadu akan mempertimbangkan faktor yang berasal dari luar dirinya. Pengaruh dari orang-orang disekitarnya seperti teman, keluarga, dosen, atau yang lainnya akan menjadi faktor pertimbangan tersendiri untuk memutuskan akan melakukan perilaku pengaduan atau tidak. Faktor pertimbangan tersebut akan menjadikan motivasi tersendiri untuk melakukan atau tidak melakukan perilaku tersebut. Mahasiswa cenderung memiliki niat untuk menjadi seorang pengadu jika orang-orang disekitarnya seperti teman, keluarga, dosen, masyarakat lingkungan menyetujui atau merasa setuju dengan perilaku yang akan dilakukannya karena perilaku tersebut dipandang mulia atau memiliki manfaat bagi banyak pihak. Sebaliknya, mahasiswa cenderung enggan atau tidak memiliki niat untuk menjadi seorang pengadu jika orang-orang disekitarnya tidak menyetujui perilaku yang akan dilakukannya karena dianggap tidak memiliki manfaat yang berarti bagi banyak pihak.Berdasarkan penjelasan diatas maka dapat dirumuskan sebuah hipotesis sebagai berikut:

\section{H2: Norma subjektif berpengaruh positif terhadap niat melakukan pengaduan. Pengaruh Kontrol Perilaku Persepsian Terhadap Niat Melakukan Pengaduan}

Setiap perilaku tidak bisa sepenuhnya dikontrol oleh setiap individu yang mungkin saja faktor tersebut

Jurnal Akuntansi Indonesia 
menjadi pertimbangan bagi individu tersebut untuk tetap melakukan perilaku atau tidak melakukan perilaku sehingga memunculkan kontruk baru yang bernama kontrol perilaku persepsian yang berfungsi sebagai variabel pengontrol perilaku (Hartono, 2008). Kontrol perilaku persepsian dapat didefinisikan sebagai suatu persepsi mengenai tingkat kemudahan atau kesulitan dalam melakukan perilaku (Ajzen, 1991). Kemudahan atau kesulitan inilah yang dapat mempengaruhi niat individu dalam berperilaku. Sulistomo (2011) menjelasakan bahwa setiap individu akan memiliki niat untuk melakukan perilaku jika mereka memiliki persepsi bahwa berbagai kesulitan untuk melakukan perilaku tersebut dapat dikontrol dan merasa yakin bahwa perilakunya tersebut dapat dilakukan. Park dan Blenkinsopp (2009), Winardi (2013), Putra dan Basuki (2015) menemukan bahwa kontrol perilaku persepsian mempunyai peranan untuk bisa memprediksi niat seseorang dalam melakukan suatu perilaku tertentu.

Mahasiswa cenderung memiliki niat untuk melakukan pengaduan jika mereka mempunyai kepercayaan dan keyakinan bahwa perilaku tersebut dianggap mudah untuk dilakukan. Kepercayaan tersebut menjadikan motivasi bagi mahasiswa bahwa perilaku tersebut bisa dikontrol jika terjadi hambatan-hambatan dan masih menjadi batas kewajaran untuk dilakukan. Tetapi jika perilaku tersebut dianggap sulit untuk dilakukan atau terdapat hambatan yang mungkin saja sulit untuk dikontrol maka mahasiswa cenderung untuk enggan atau tidak memiliki niatan untuk melakukan pengaduan. Berdasarkan penjelasan diatas maka dapat dirumuskan sebuah hipotesis sebagai berikut:

\section{H3: Kontrol perilaku persepsian berpengaruh positif terhadap niat melakukan pengaduan.}

\section{Populasi dan Sampel}

\section{METODE PENELITIAN}

Populasi dari penelitian ini adalah seluruh mahasiswa aktif diploma 3 ekonomi di salah satu Universitas Swasta yang terletak di Daerah Istimewa Yogyakarta yang terdiri dari tiga prodi, yaitu akuntansi, manajemen, dan perbankan \& keuangan. Berdasarkan data yang didapat dari pihak akademik diploma 3 ekonomi tercatat bahwa jumlah mahasiswa aktif berjumlah 745 mahasiswa yang terdiri dari tiga prodi. Sedangkan penentuan jumlah sampel yang akan digunakan dalam penelitian ini adalah dengan menggunakan rumus Slovin.

Keterangan: $\quad \begin{array}{ll}\mathrm{n} & =\text { Jumlah Sampel } \\ & \mathrm{N}=\text { Jumlah Populasi } \\ & \mathrm{a}=\text { Tingkat Toleransi }\end{array}$

Berdasarkan rumus slovin di atas maka dapat diketahui hasil sampel yang akan diambil dalam penelitian ini sebagai berikut:

$$
\begin{aligned}
& =88,16 \\
& =88 \text { (dibulatkan) }
\end{aligned}
$$

Metode pengambilan sampel dalam penelitian ini menggunakan nonprobabilitas dengan teknik pengambilan sampel menggunakan convenience sampling. Teknik ini merupakan teknik pengambilan sampel yang bisa dilakukan dengan cara memilih sampel secara bebas sekehendak perisetnya (Hartono, 2013) sehingga dianggap cepat, mudah, dan murah dalam memperoleh data (Sekaran, 2006). 


\section{Definisi Operasional dan Pengukuran Variabel Sikap Terhadap Perilaku}

Sikap merupakan pandangan atau penilaian dari seorang individu tentang seberapa besar manfaat yang akan didapat jika perilaku tersebut dilakukan (Ajzen, 1991). Variabel ini diambil dari Putra dan Basuki (2015) dan diukur dengan menggunakan dua indikator. Indikator pertama digunakan untuk menilai kepercayaan terhadap suatu perilaku tertentu (behavioral belief). Sedangkan indikator yang kedua digunakan sebagai bentuk evaluasi mengenai seberapa penting perilaku tersebut jika harus dilakukan (evaluation of important).

\section{Norma Subjektif}

Norma subjektif merupakan persepsi atau pandangan seseorang terhadap kepercayaan-kepercayaan yang berasal dari orang lain dan dapat mempengaruhi niat seseorang untuk melakukan atau tidak melakukan perilaku (Hartono, 2008). Variabel ini diambil dari Putra dan Basuki (2015) dan diukur dengan menggunakan dua indikator. Indikator yang pertama digunakan untuk menilai keyakinan normatif (normative belief). Sedangkan indikator yang kedua digunakan untuk menilai motivasi untuk mematuhi (motivation of comply) harapan orang disekitarnya.

\section{Kontrol Perilaku Persepsian}

Kontrol perilaku persepsian merupakan persepsi atau pandangan mengenai tingkat kemudahan atau kesulitan jika perilaku tersebut dilakukan (Ajzen, 1991). Variabel ini diambil dari Putra dan Basuki (2015) dan diukur dengan menggunakan dua indikator. Indikator yang pertama digunakan untuk menilai keyakinan mengenai kemampuan dalam mengendalikan perilaku (control belief). Sedangkan indikator yang kedua digunakan untuk menilai persepsi tentang kekuatan jika perilaku tersebut dilakukan (perceived power).

\section{Niat Melakukan Pengaduan}

Niat melakukan pengaduan adalah keinginan seseorang untuk melakukan perilaku pengaduan. Variabel niat diambil dari Sulistomo dan Prastiwi (2011) dan diukur dengan menggunakan tiga indikator. Indikator yang pertama menggambarkan mengenai seberapa besar niat mahasiswa untuk melakukan pengaduan. Indikator yang kedua menggambarkan mengenai seberapa besar rencana mahasiswa untuk melakukan pengaduan. Indikator yang ketiga menggambarkan mengenai seberapa besar usaha mahasiswa untuk melakukan pengaduan.

\section{Analisis Regresi Berganda}

\section{HASIL dan PEMBAHASAN}

Analisis regresi berganda merupakan suatu analisis yang bertujuan untuk memprediksi pengaruh lebih dari satu variabel independen terhadap satu variabel dependen. Variabel-variabel yang terlibat adalah variabel sikap, norma subjektif, dan kontrol perilaku persepsian yang keseluruhan variabel tersebut nantinya akan diuji dan dilihat pengaruhnya terhadap variabel niat melakukan pengaduan. Berdasarkan hasil pengujian regresi yang telah dilakukan (lihat tabel 1 dibagian lampiran) maka didapatkan persamaan regresi sebagai berikut:

$$
Y=-0,031+0,355 X 1+0,662 X 2-0,011 X 3+e
$$


Berdasarkan persamaan regresi diatas maka dapat diketahui bahwa nilai konstanta adalah sebesar -0,031 yang menunjukkan bahwa jika tidak ada sikap, norma subjektif, dan kontrol perilaku persepsian maka niat melakukan pengaduan memiliki nilai -0,031. Kemudian sikap terhadap perilaku (X1) memiliki nilai koefisien regresi sebesar 0,355 yang menunjukkan bahwa setiap 1 penambahan (dikarenakan tanda +) pada sikap maka akan meningkatkan niat melakukan pengaduan sebesar 0,355 atau 35,5\%. Selain itu norma subjektif (X2) memiliki nilai koefisien regresi sebesar 0,662 yang menunjukkan bahwa setiap 1 penambahan (dikarenakan tanda + ) pada norma subjektif maka akan meningkatkan niat melakukan pengaduan sebesar 0,662 atau $66,2 \%$. Kontrol perilaku persepsian (X3) memiliki nilai koefisien regresi sebesar -0,011 yang menunjukkan bahwa setiap 1 penambahan (dikarenakan tanda -) pada kontrol perilaku persepsian maka akan menurunkan niat melakukan pengaduan sebesar 0,011 atau 1,1\%.

\section{Uji t (Parsial)}

Uji t digunakan untuk menjelaskan hipotesis-hipotesis yang telah dirumuskan sebelumnya. Berdasarkan Tabel 1 (lihat dibagian lampiran) dapat diketahui nilai t hitung dan nilai probabilitasnya untuk masingmasing variabel independennya dan dapat dijadikan sebagai dasar pengambilan keputusan dengan cara membandingkannya antara $\mathrm{p}$ value dengan tingkat signifikansi yaitu sebesar 0,05 . Hipotesis diterima jika $\mathrm{p}$ value $<0,05$ begitupula sebaliknya hipotesis akan ditolak jika $p$ value $>0,05$.

Hasil pengujian regresi untuk variabel sikap terhadap perilaku (X1) memiliki nilai t hitung sebesar 24,059 dan probabilitas sebesar 0,00 yang berarti bahwa p value $<0,05$. Nilai tersebut dapat membuktikan Ho ditolak atau menerima Ha yang berarti bahwa terdapat pengaruh positif antara variabel sikap terhadap niat melakukan pengaduan. Oleh karena itu hipotesis yang pertama dinyatakan diterima. Kemudian hasil pengujian regresi untuk variabel norma subjektif (X2) memiliki nilai t hitung sebesar 48,990 dan probabilitas sebesar 0,000 yang berarti bahwa $p$ value $<0,05$. Nilai tersebut dapat membuktikan Ho ditolak atau menerima Ha yang berarti bahwa terdapat pengaruh positif antara variabel norma subjektif terhadap niat melakukan pengaduan. Oleh karena itu hipotesis yang kedua dinyatakan diterima. Selain itu hasil pengujian regresi untuk variabel kontrol perilaku persepsian memiliki nilai nilai t hitung sebesar -1,203 dan probabilitas sebesar 0,232 yang berarti bahwa $\mathrm{p}$ value $>0,05$. Nilai tersebut dapat membuktikan Ho diterima atau menolak Ha yang berarti bahwa tidak ada pengaruh positif variabel kontrol perilaku persepsian terhadap niat melakukan pengaduan. Oleh karena itu hipotesis yang ketiga dinyatakan ditolak.

\section{Uji F (Simultan)}

Uji F digunakan untuk menguji apakah seluruh variabel independen yang digunakan dalam penelitian ini jika dimasukkan ke dalam model regresi memiliki pengaruh secara bersama-sama (simultan) terhadap variabel dependen. Berdasarkan tabel 2 (lihat dibagian lampiran) diketahui memiliki nilai signifikansinya sebesar 0,000 yang menunjukkan bahwa variabel sikap, norma subjektif, dan kontrol perilaku persepsian secara simultan atau bersama-sama berpengaruh terhadap niat melakukan pengaduan. 


\section{PEMBAHASAN \\ Sikap Terhadap Perilaku Berpengaruh Positif Terhadap Niat Melakukan Pengaduan}

Berdasarkan pengujian regresi yang telah dilakukan sebelumnya didapatkan hasil bahwa sikap terhadap perilaku berpengaruh positif terhadap niat melakukan pengaduan. Hal ini disebabkan karena pandangan atau persepsi mahasiswa mengenai manfaat yang besar ketika mereka mengadukan suatu tindakan kecurangan di tempat atau lingkungannya. Pandangan atau persepsi yang positif ini dapat memunculkan atau memicu mahasiswa dalam membentuk niat untuk melakukan pengaduan. Niat tersebut yang nantinya akan dikonversi atau diwujudkan menjadi suatu perbuatan nyata untuk melakukan pengaduan. Hasil penelitian ini sejalan dengan hasil penelitian yang dilakukan oleh Park dan Blenkinsopp (2009), Alleyne, Hudaib, dan Pike (2013), Winardi (2013), dan Sulistomo (2011) yang menunjukkan bahwa sikap terhadap perilaku berpengaruh positif terhadap niat melakukan pengaduan.

\section{Norma Subjektif Berpengaruh Positif Terhadap Niat Melakukan Pengaduan}

Berdasarkan pengujian regresi yang telah dilakukan sebelumnya didapatkan hasil bahwa norma subjektif berpengaruh positif terhadap niat melakukan pengaduan. Hal ini disebabkan karena mahasiswa merasa bahwa tindakan yang akan dilakukan untuk melakukan pengaduan atas tindakan kecurangan yang terjadi di tempat atau lingkungannya akan mendapatkan dukungan dari orang-orang disekitarnya, seperti keluarga, teman, dosen, dan yang lain. Dukungan dari orang-orang disekitar tersebut yang nantinya akan memunculkan motivasi dan rasa percaya diri bahwa tindakan atau perilaku yang akan dilakukannya mendapatkan dukungan dari sekitarnya sehingga perbuatan ini dianggap benar dan pantas untuk dilakukan. Hasil penelitian ini sejalan dengan hasil penelitian yang dilakukan oleh Park dan Blenkinsopp (2009), Winardi (2013), Sulistomo (2011), dan Putra dan Basuki (2015) yang menunjukkan bahwa norma subjektif berpengaruh positif terhadap niat melakukan pengaduan.

\section{Kontrol Perilaku Persepsian Tidak Berpengaruh Positif Terhadap Niat Melakukan Pengaduan}

Berdasarkan hasil pengujian regresi yang telah dilakukan sebelumnya didapatkan hasil bahwa kontrol perilaku persepsian tidak berpengaruh positif terhadap niat melakukan pengaduan. Hal ini disebabkan karena mahasiswa tidak mempertimbangkan isu-isu mengenai kesulitan yang akan didapat jika melakukan pengaduan. Mahasiswa berpandangan bahwa tindakan kecurangan yang dapat merugikan harus tetap dilaporkan dan diungkap meskipun ancaman-ancaman seperti pengabaian laporan, kesulitan dalam melaporakan, adanya potensi untuk balas dendam dari orang yang terlapor menjadi satu tantangan yang tersendiri bagi mahasiswa. Hasil penelitian ini sejalan dengan hasil penelitian yang dilakukan oleh Putra dan Basuki (2015) yang menunjukkan bahwa kontrol perilaku persepsian tidak berpengaruh positif terhadap niat melakukan pengaduan.

\section{SIMPULAN}

Berdasarkan pengujian hipotesis yang telah dilakukan sebelumnya maka disimpulkan bahwa sikap terhadap perilaku berpengaruh positif terhadap niat melakukan pengaduan. Hal ini dibuktikan dengan hasil 
p value yang lebih kecil dari tingkat signifikansi 5\%. Kemudian norma subjektif berpengaruh positif terhadap niat melakukan pengaduan. Hal ini dibuktikan dengan hasil $p$ value yang lebih kecil dari tingkat signifikansi 5\%. Sedangkan kontrol perilaku persepsian tidak berpengaruh positif terhadap niat melakukan pengaduan. Hal ini dibuktikan dengan hasil $p$ value yang lebih besar dari tingkat signifikansi $5 \%$. Selain itu variabel sikap terhadap perilaku, norma subjektif, dan kontrol perilaku persepsian secara simultan berpengaruh signifikan terhadap niat melakukan pengaduan.

\section{Katerbatasan}

Penelitian yang telah dilakukan ini memiliki beberapa keterbatasan, diantaranya jika dilihat dari jumlah sebaran mahasiswa yang menjadi responden keterlibatan mahasiswa angkatan 2017 sebagai responden masih sangat kurang hal ini mungkin disebabkan karena padatnya jadwal kuliah. Kemudian yang kedua pengumpulan data yang terbilang cukup lama dikarenakan kesibukan responden saat kuliah sehingga responden tidak mempunyai cukup waktu untuk menjadi responden. Selain itu objek yang digunakan dalam penelitian ini hanya menggunakan satu tempat di salah satu Universitas Swasta sehingga hasil penelitian ini tidak bisa digeneralisasi secara umum.

\section{Saran}

Berdasarkan keterbatasan-keterbatasan yang telah dikemukakan sebelumnya maka saran bagi peneliti selanjutnya diantaranya memilih responden secara merata dari berbagai tahun angkatan agar setiap tahun angkatan mahasiswa terwakili seluruhnya. Kemudian memilih waktu yang tepat dalam membagikan kuesioner kepada responden dan mendampingi pada saat pengisiannya agar kuesioner lebih cepat kembali dan jika ada beberapa pertanyaan dari responden langsung bisa dijelaskan pada saat itu juga. Selain itu objek dalam penelitian selanjutnya juga sebaiknya ditambah supaya hasil penelitian bisa digeneralisasi secara umum. 


\section{DAFTAR PUSTAKA}

Achmat, Z. (2010). Theory of Planned Behavior, Masihkah Relevan. Retrieved from http://zakarija.staff.umm. ac.id.html.

Ajzen. (1991). The Theory of Planned Behavior. Organizational Behavior and Human Decision Processes, 50: 179211.

Alleyne, P., Hudaib, M., and Pike, R. (2013). Towards a Conceptual Model of Whislte-blowing Intention Among External Auditors. The British Accounting Review, 45: 10-23.

Cortina, L.M., and Magley, V.J. (2003). Raising Voice, Risking Retaliation: Events Following Interpersonal Mistreatment in the Workplace. Journal of Occupational Health Psychology, 8: 247-265.

Egi. (2016). Korupsi di Perguruan Tinggi, diakses pada tanggal 15 Februari 2018 dari http://icw.or.id/wS4.

Elias, R. (2008). Auditing Students' Professional Commitment and Anticipatory Socialization and Their Relationship to Whislteblowing. Managerial Auditing Journal, 23: 283-294.

Ghozali, I. (2005). Aplikasi Analisis Multivariat dengan Program SPSS. Semarang: Badan Penerbit Universitas Diponegoro.

Hartono, J. (2008). Metodologi Penelitian Sistem Informasi. Yogyakarta, Indonesia: Penerbit Andi.

Hartono, J. (2008). Sistem Informasi Keperilakuan (Edisi 2). Yogyakarta, Indonesia: Penerbit Andi.

Hartono, J. (2013). Metodologi Penelitian Bisnis: Salah Kaprah dan Pengalaman-pengalaman. Yogyakarta, Indonesia: BPFE UGM.

Kreshastuti, D.K. (2014). Analisis Faktor-Faktor yang Mempengaruhi Intensi Auditor untuk Melakukan Tindakan Whislteblowing. Skripsi, Universitas Diponegoro, Semarang.

Mesmer-Magnus, J.R., and Viswesvaran, C. (2005). Whislteblowing in Organization: An Examination of Correlates of Whistleblowing Intention, Actions, and Retaliation. Journal of Business Ethics, 62: 277-297.

Park, H., and Blenkinsopp, J. (2008). Whistleblowing as Planned Behavior - A Survey of South Korean Police Officers. Journal of Business Ethics, 85: 545-556.

Putra, A.F., and Basuki, H. (2015). Pengaruh Faktor Individual dan Situasional Terhadap Niat Melakukan Whistleblowing, Accounting and Bussiness Information System Journal, 12, 1-10.

Santoso, S. (2000). Buku Latihan SPSS Statistik Parametrik. Jakarta, Indonesia: PT Elex Media Komputindo.

Schultz, J.J., et al (1993). An Investigation of the Reporting of Questionable Acts in an International Setting. Journal of Accounting Research, 31: 75-103.

Sekaran, U. (2006). Metodologi Penelitian Untuk bisnis (Edisi 4). Jakarta, Indonesia: Salemba Empat.

Sulistomo, A., and Prastiwi, A. (2011). Persepsi Mahasiswa Akuntansi Terhadap Pengungkapan Kecurangan. Skripsi, Universitas Diponegoro, Semarang.

Winardi, R.D. (2013). The Influence of Individual and Situational Factors on Lower-Lavel Civil Servants' Whislteblowing Intention in Indonesia. Thesis, Sheffield Hallam University, England.

Zhang, J., Chiu, R., and Wei, L. (2008). Decision-Making Process of Internal Whislteblowing Behavior in China: Empirical Evidence and Implications. Journal of Business Ethics, 88: 25-41. 


\section{LAMPIRAN}

TABEL 1

Hasil Regresi Berganda

\begin{tabular}{|c|c|c|c|}
\hline Variabel Bebas & Koef. Beta & t-hitung & Probabilitas \\
\hline Konstanta & $-0,031$ & $-0,465$ & 0,643 \\
\hline Sikap (X1) & 0,355 & 24,059 & 0,000 \\
\hline Norma Subjektif (X2) & 0,662 & 48,990 & 0,000 \\
\hline Kontrol Perilaku Persepsian (X3) & $-0,011$ & $-1,203$ & 0,232 \\
\hline $\mathrm{R}$ & & 0,989 & \\
\hline R Square & & 0,979 & \\
\hline Adjusted R Square & & 0,978 & \\
\hline F Hitung & & $1.303 \mathrm{E} 3$ & \\
\hline
\end{tabular}

Sumber: Keluaran dari SPSS 16

TABEL 2

Hasil Uji F

\begin{tabular}{llll}
\hline Model & & $\mathrm{F}$ & \multicolumn{2}{c}{ Sig. } \\
\hline & Regression & $1.303 \mathrm{E} 3$ & \\
1 & Residual & & $.000^{\mathrm{a}}$ \\
& Total & & \\
& & & \\
\hline
\end{tabular}

Sumber: Keluaran dari SPSS 16 